\title{
Macro Nutrient and Selected Heavy Metals in Powered Herbal Medicine Sold in Nigeria
}

\author{
Ayobami Omozemoje Aigberua ${ }^{1}$, Sylvester Chibueze Izah $^{2 *}$ \\ ${ }^{1}$ Department of Chemical Sciences, Faculty of Science, Niger Delta University, Wilberforce Island, Bayelsa \\ State, Nigeria \\ ${ }^{2}$ Department of Biological Sciences, Faculty of Science, Niger Delta University, Wilberforce Island, Bayelsa \\ State, Nigeria
}

${ }^{*}$ Corresponding Author: Sylvester Chibueze Izah, Department of Biological Sciences, Faculty of Science, Niger Delta University, Wilberforce Island, Bayelsa State, Nigeria

\begin{abstract}
This study evaluated the level of macro nutrient and selected heavy metals in powered herbal medicines sold in Nigeria. Five brands of powdered herbal medicines were purchased in triplicate across retail outlets in Port Harcourt, Rivers state, Nigeria. The trace metals (viz: nickel, iron, zinc, lead and cobalt) and macro nutrients (viz: calcium, magnesium, sodium and potassium) in the herbal medicines were predigested, further concentrated, and prepared for analysis using the atomic absorption spectrometer. Results showed that the level of potassium, magnesium, sodium and calcium ranged from $13.42-204.03 \mathrm{mg} / \mathrm{kg}$, $10.26-32.09 \mathrm{mg} / \mathrm{kg}, 6.84-8.01 \mathrm{mg} / \mathrm{kg}$ and $20.44-172.37 \mathrm{mg} / \mathrm{kg}$ respectively. The concentration of the macro nutrients were in the order; calcium> potassium > magnesium> sodium. Nickel and lead was not detected in the powdered herbs. Zinc, iron and cobalt concentration ranged from $<0.001-0.231 \mathrm{mg} / \mathrm{kg}$, $6.817-15.253 \mathrm{mg} / \mathrm{kg}$ and $<0.001-0.014 \mathrm{mg} / \mathrm{kg}$ respectively. Among the trace metals, the percentage occurrence were $0.00 \%, 0.00 \%, 20.00 \%, 40.00 \%$ and $100.00 \%$ for nickel, lead, cobalt, zinc and iron respectively. Analysis of variance revealed that there was significant variation $(P<0.05)$ among the products for each of the detected metals. Findings of this study suggest that the herbal medicine is within safe level that could induce toxicity on the users based on the parameters analyzed.
\end{abstract}

Keywords: Humans health, Herbal Medicine, Macro nutrients, Trace metals, Plants

\section{INTRODUCTION}

Plants have been variously reported as potential alternatives to synthetic drugs especially antibiotics production (Epidi et al., 2016a, b; Kigigha et al., 2015, 2016, 2018 a, b; Izah et al., 2018a-d; Izah, 2018 Izah and Aseibai, 2018). Several plant species and their different parts have been reported to possess pharmacological properties. In some instances, the therapeutic claims of some of the plants have been validated while several others have not been tested (Aigberua and Izah, 2019).

Till date, herbal medicine is the prevalent source of medicine for different treatments. Herbal medicine practice can be traced back to human history, and its wide use in different regions of the world. Reports have variously indicated that $70-80 \%$ of global population still rely on traditional medicine for the treatment of different types of diseases (Epidi et al., $2016 \mathrm{a}$, b; Kigigha et al., 2015, 2016, 2018 a, b; Izah et al., 2018a-d; Izah, 2018; Onimisi et al., 2016). Further survey suggests that a significant number of individuals who rely on herbal medicines are from developing nations.

Globally, different types of herbal medicine products are available. Majority of the plants depend on plant species that are peculiar to the people who produce these herbal medicines. Again, the preparation, use and treatment options vary based on the product, its active ingredients, as well as the type of disease been treated. Furthermore, same plant species can be applied in different forms and/or treatment of varying ailments (Aigberua and Izah, 2019). These mainly depend on the knowledge of the medicine plant by the indigenous people of the region. Again, the use of herbal medicine is predominant in the rural setting of many developing countries.

Like modern medicine, some herbal medicines are imported into the country. In Nigeria, some of the herbal medicine products currently in the market are imported. In different region, most traditional 
medicine practitioners have associations regulating their activities. For instance, In Nigeria, National Agency for Drug Administration and Control (NAFDAC) - the Nigerian body responsible for the regulation of food and drug matters (Omimisi et al., 2016) are also involved in registration of herbal medicines. In addition, National Association of Traditional Medicine Practitioner of Nigeria is also involved in regulating the activities of traditional medicine practitioners (NATMPN) (Aigberua and Izah, 2019). In spite of these legislations, some of the herbal medicines in the market have no NAFDAC or NATMPN registration numbers.

Herbal medicines can be processed into liquid or powdered forms. Heavy metals have been widely reported as common environmental contaminants occurring in surface water (Izah et al., 2016), fishes (Izah and Angaye, 2016; Aigberua and Tarawou, 2017), food and beverages (Izah et al., 2017a; Kigigha et al., 2017, 2018c), soil (Izah et al., 2017b-d, 2018e). Plants have the tendency to uptake trace metal ions from the soil. Most of the metals (essential elements) are required for maximum growth and productivity, while others (non-essential elements) do not have biological functions. At certain concentrations that exceed recommended limits, trace metals can become toxic to the body. In addition, macro nutrients such as calcium, magnesium, potassium and sodium play essential role in biological diversity (including plants and animals). Excess concentration or deficiency of these macro nutrients bring about dysfunctioning of metabolic activities in the body.

Most claims of the traditional medicine practitioners are increasingly being validated through scientific research to unveil the active chemical constituents and therapeutic effects of the plants. There is also the need to ascertain the level of trace metals in the herbal medicine so as to avoid toxicity and reactions due to these trace metals. Therefore, this study aimed at the level of macro nutrient and selected heavy metals in powdered herbal medicines sold in Nigeria

\section{MATERIALS AND METHOD}

\subsection{Sample Collection}

Five brands of powdered herbal medicines were purchased in triplicate from retail outlets in Port Harcourt, Rivers State, Nigeria. Only samples with date of manufacture and expiration were purchased. Other information such as ingredients, place of production/manufacture, National Agency for Food, Drug and Administration and Control (NAFDAC) registration and herbal number of the various brands are presented in Table 1.

Table1. Sample information for herbs sold in Nigeria

\begin{tabular}{|c|c|c|c|c|c|c|}
\hline $\mathrm{S} / \mathrm{N}$ & Sample code & Ingredients & Dates & $\begin{array}{l}\text { Production } \\
\text { place }\end{array}$ & $\begin{array}{l}\text { Herbal } \\
\text { group }\end{array}$ & NAFDAC \\
\hline 1 & GSH & $\begin{array}{l}\text { Ginseng panax } \\
\text { Aloe Vera } \\
\text { Zingiber officinale } \\
\text { Carica papaya }\end{array}$ & $\begin{array}{l}\text { Kumasi, } \\
\text { Ghana. }\end{array}$ & $\begin{array}{l}\text { January } \\
2017 \\
\text { January } \\
2020\end{array}$ & $\begin{array}{l}\text { Has } \\
\text { herbal } \\
\text { number }\end{array}$ & - \\
\hline 2 & ORG & $\begin{array}{l}\text { Carica papaya } \\
\text { Magnifera indica } \\
\text { Newbouidia laevis } \\
\text { Azadirachta Indica } \\
\text { Jasminum officiorli } \\
\text { Aloe barbadensis } \\
\text { Ginseng }\end{array}$ & $\begin{array}{l}\text { Onitsha, } \\
\text { Nigeria. }\end{array}$ & $\begin{array}{l}\text { April } 2017- \\
\text { April } 2020\end{array}$ & - & Yes \\
\hline 3. & MHP & $\begin{array}{ll}\text { 1. } & \text { Zingiber officinale } \\
\text { 2. } & \text { Psidium guajava } \\
\text { 3. } & \text { Xylopia aethiopica } \\
\text { 4. } & \text { Cymbopogon } \\
& \text { citratus } \\
\text { 5. } & \text { Aloe vera } \\
\text { 6. } & \text { Ginseng }\end{array}$ & $\begin{array}{l}\text { Port } \\
\text { Harcourt, } \\
\text { Nigeria }\end{array}$ & $\begin{array}{l}\text { June } 2017- \\
\text { May } 2020\end{array}$ & - & Yes \\
\hline 4. & UNP & $\begin{array}{l}\text { Aloe vera } \\
\text { Ginseng plant } \\
\text { Moringa plant }\end{array}$ & $\begin{array}{l}\text { Edo State, } \\
\text { Nigeria }\end{array}$ & $\begin{array}{l}\text { June } 2017- \\
\text { December } \\
2022\end{array}$ & - & - \\
\hline 5 . & GWM & $\begin{array}{l}\text { Mangifera indica } \\
\text { Carica papaya } \\
\text { Psidium guajoba }\end{array}$ & $\begin{array}{l}\text { Imo state, } \\
\text { Nigeria }\end{array}$ & $2018-2021$ & - & Yes \\
\hline
\end{tabular}




\begin{tabular}{|l|l|l|l|l|l|}
\hline & $\begin{array}{l}\text { Bread fruit } \\
\text { Masularia acuminate } \\
\text { Citrus Limon } \\
\text { Cymbopogon Spp }\end{array}$ & & & & \\
\hline
\end{tabular}

\subsection{Sample Preparation and Analysis of Trace Metals and Macro Nutrients}

Exactly $2.5 \mathrm{~g}$ each of herbal medicines in powdered dosage forms were transferred into $125 \mathrm{ml}$ glass beakers. Exactly $10 \mathrm{ml}$ of conc. $\mathrm{HNO}_{3}$ was added and mixture was pre-digested under room temperature conditions inside a fume cupboard, and left overnight. The mixture was carefully heated on a hot plate at low heat until all nitrous oxide fumes had completely evolved. About $4 \mathrm{ml}$ of $70 \%$ perchloric acid $\left(\mathrm{HClO}_{4}\right)$ was added prior to heating on a hot plate, this continued until the mixture attained near-dryness. The concentrate was allowed to cool before been filtered into a $25 \mathrm{ml}$ volumetric flask using whatman filter paper no. 42. The filtrate was diluted to mark with distilled water (Umar et al., 2016).

The working standards of zinc, iron, nickel, cobalt and lead were prepared by diluting concentrated stock solutions of $1,000 \mathrm{mg} / \mathrm{L}$ (AccuNoHaz, New Haven, CT, USA) to $0.5,1.0,2.0$ and $5.0 \mathrm{mg} / \mathrm{L}$ concentrations respectively. The samples and reagent blanks were aspirated into the GBC Avanta PM A6600 atomic absorption spectrophotometer (AAS) and the corresponding metal concentrations were reported in $\mathrm{mg} / \mathrm{kg}$ units. The different elements were analyzed at varying wavelengths viz: calcium $(422.7 \mathrm{~nm})$, magnesium $(202.6 \mathrm{~nm})$, sodium $(330.2 \mathrm{~nm})$ and potassium $(769.9 \mathrm{~nm})$ (macro nutrients) and zinc $(213.9 \mathrm{~nm})$, iron $(248.3 \mathrm{~nm})$, nickel $(232.0 \mathrm{~nm})$, cobalt $(240.7 \mathrm{~nm})$ and lead $(217.0 \mathrm{~nm})$ (trace metals).

\subsection{Statistical Analysis}

Statistical package for social science (version 20) was used for the statistical analysis. Data was expressed as mean \pm standard deviation $(n=3)$. One way Analysis of variance (ANOVA) was carried out at $\mathrm{P}<0.05$. Waller-Duncan statistics was used to determine the source of the observed variation.

\section{RESUlTS AND DISCUSSION}

The macro nutrients in some herbal medicines sold in Nigeria is presented in Table 1. The concentration of potassium, magnesium, sodium and calcium ranged from $13.42-204.03 \mathrm{mg} / \mathrm{kg}$, $10.26-32.09 \mathrm{mg} / \mathrm{kg}, 6.84-8.01 \mathrm{mg} / \mathrm{kg}$ and $20.44-172.37 \mathrm{mg} / \mathrm{kg}$ respectively. Basically, there was significant variation at $\mathrm{p}<0.05$ among the products and across each of the parameters. The concentration of potassium in each of the products were in the order; GWM $>$ GSH $>$ UNP $>$ MHP $>$ ORG. Magnesium level was in the order; $\mathrm{UNP}>\mathrm{MHP}=\mathrm{GWM}>\mathrm{GSH}>\mathrm{ORG}$. Sodium was in the order GSH $<\mathrm{MHP} \sim \mathrm{ORG} \sim \mathrm{GWM}<\mathrm{UNP}$. Calcium concentration was in the order; $\mathrm{UNP}<\mathrm{MHP}<\mathrm{GSH}<\mathrm{ORG}<\mathrm{GWM}$. In general, the concentration of the macro nutrients were in the order; calcium>potassium>magnesium>sodium. The variations in the trend of the products for individual macro nutrients could be associated to differences in herbs used for the manufacture of the medicine which typically have varying genetic and biochemical compositions. These macro nutrients especially Sodium, potassium and calcium are mostly indispensable in the body. Imbalance in the level of these macronutrients could be harmful to the body (Aigberua et al., 2018). Sodium is an important extracellular fluid (Opoku-Okrah et al., 2015) required for the maintenance of electrolyte, fluid balance, nerve impulse and some organ with metabolic functions (Aigberua and Izah, 2019; Aigberua et al., 2018; Izah et al., 2017b). Potassium is vital during carbohydrate metabolism, amino acid synthesis and other enzymatic processes essential for biochemical reactions in cells (Aigberua et al., 2018; Opoku-Okrah et al., 2015; Haas, 2011; Izah et al., 2017e). Potassium also aids in the maintenance of body $\mathrm{pH}$ and skeletal salt balance (Aigberua and Izah, 2019; Aigberua et al., 2018; Palacios, 2006; Izah et al., 2017e). Calcium is required for normal bone and skeleton formation and muscle contraction (Aigberua et al., 2018; Izah et al., 2017e; Palacios, 2006). Magnesium is required for bone and skeleton formation, ATP metabolism (Palacios, 2006; Izah et al., 2017e; Aigberua et al., 2018). Abnormal concentration of this macro nutrients could lead to chronic medical conditions (Aigberua and Izah, 2019; Aigberua et al., 2018), while very low values could also be detrimental to the body. Based on the body requirement for these macronutrients, the concentration in the powdered herbal medicine under study may not be above concentrations that are harmful to human health. 
Table1. Some mineral in powdered herbal medicine sold in Nigeria

\begin{tabular}{|l|l|l|l|l|}
\hline Sample code & $\mathrm{K}(\mathrm{mg} / \mathrm{kg})$ & $\mathrm{Mg}(\mathrm{mg} / \mathrm{kg})$ & $\mathrm{Na}(\mathrm{mg} / \mathrm{kg})$ & $\mathrm{Ca}(\mathrm{mg} / \mathrm{kg})$ \\
\hline MHP & $18.96 \pm 0.70 \mathrm{~b}$ & $20.84 \pm 0.22 \mathrm{c}$ & $7.88 \pm 0.12 \mathrm{~b}$ & $89.71 \pm 0.70 \mathrm{~d}$ \\
\hline GWM & $204.03 \pm 3.97 \mathrm{e}$ & $20.75 \pm 0.17 \mathrm{c}$ & $8.31 \pm 0.31 \mathrm{c}$ & $20.44 \pm 0.46 \mathrm{a}$ \\
\hline UNP & $47.25 \pm 0.89 \mathrm{c}$ & $32.09 \pm 1.05 \mathrm{~d}$ & $8.76 \pm 0.03 \mathrm{~d}$ & $172.37 \pm 2.30 \mathrm{e}$ \\
\hline ORG & $13.42 \pm 0.40 \mathrm{a}$ & $10.26 \pm 0.25 \mathrm{a}$ & $8.01 \pm 0.02 \mathrm{bc}$ & $30.35 \pm 0.47 \mathrm{~b}$ \\
\hline GSH & $53.46 \pm 2.56 \mathrm{~d}$ & $12.75 \pm 0.20 \mathrm{~b}$ & $6.84 \pm 0.09 \mathrm{a}$ & $46.53 \pm 0.45 \mathrm{c}$ \\
\hline
\end{tabular}

Data is expressed as mean \pm standard deviation; Different letters along the column indicate significant variations $(P<0.05)$ according to Waller Duncan statistics

The concentration of heavy metals in some powdered herbal medicine sold in Nigeria is presented in Table 2. Nickel and lead were below the detection limit $(<0.001 \mathrm{mg} / \mathrm{kg})$. This suggests that there is no toxicity associated with these two heavy metals. Typically, lead is one of the environmental contaminants with no biological function. Its presence could be toxic to humans. Authors have widely reported that lead could affect haematological, nervous, immune, renal, skeletal, muscular, reproductive, and cardiovascular systems causing varying levels of impairment and dysfunction (Dghaim et al., 2015; Idris et al., 2013; Muhammad et al., 2014; Izah et al., 2016). The concentration of lead was lower than $10 \mathrm{mg} / \mathrm{kg}$ for prepared herbal medicines as recommended by WHO (2007). On the other hand, nickel could be poisonous at high concentrations causing gastrointestinal disorder, skin dermatitis, lung and kidney impairment, reproductive, immune, and cardiovascular disorder (Das et al., 2008; Izah et al., 2016). In spite of the unavailability of regulatory limits for nickel, its levels in this study suggests non-toxicity in the powdered herbal medicines.

Zinc concentration was $0.241 \mathrm{mg} / \mathrm{kg}$ in UNP and $0.231 \mathrm{mg} / \mathrm{kg}$ in ORG products, while it was not detected in MHP, GWM and GSH. Furthermore, cobalt concentration was $0.014 \mathrm{mg} / \mathrm{kg}$ in MHP, while it was undetected in GWM, UNP, ORG and GSH. Iron concentration in all the products were in the range of $6.817-15.253 \mathrm{mg} / \mathrm{kg}$. The heavy metals were in the order; iron<zinc<cobalt<nickel=lead. Overall, iron was the most abundant heavy metal. This trend have been widely reported in vegetables (Izah and Aigberua, 2017), soil samples (Izah et al., 2017b-d), gari samples (Kigigha et al., 2018c), smoked fish (Kigigha et al., 2017). Zinc play essential role in humans proper growth, blood clotting, thyroid function, and protein and DNA synthesis (Dghaim et al., 2015), wound healing, immune system function, essential for cell growth, development, differentiation, homeostasis, connective tissue growth and maintenance, DNA synthesis, RNA transcription, cell division, cell activation, regulatory, catalytic, co-catalytic and structural roles in enzyme molecules, regulation of body fluid $\mathrm{pH}$, formation of collagen for hair, skin for nails growth, enhancement of mental development, and sexual functions such as prostate functioning, sperm production, secretion of testosterone (Aigberua and Izah, 2019; Chasapis et al., 2012; Prashanth et al., 2015; Izah et al., 2016 ; Izah and Angaye, 2016), functioning of metalloproteinase in the cell and tissues that play essential role in the reproductive, neurological, immune, dermatological systems, and gastrointestinal track (Prashanth et al., 2015; Izah et al., 2016). The levels of zinc reported in this study was less than 50 $\mathrm{mg} / \mathrm{kg}$ stipulated for prepared herbal medicine as recommended by WHO (2007). High concentrations of zinc could lead to stomach upset. However, the values in this study indicate no risk of toxicity due to zinc.

Typically iron play essential role in several metabolic and biochemical processes including oxygen transport, deoxyribonucleic acid synthesis, electron transport chain and regulation of cell growth and differentiation, energy production, and immunity (Lieu et al., 2001; Abbaspour et al., 2014; Dghaim et al., 2015; Beard, 2001; Izah et al., 2016, 2017a; Izah and Aigberua, 2017; Kigigha et al., 2017, 2018c). High concentration of iron is associated with dizziness, nausea, vomiting, diarrhea, joint pain, shock, and liver damage (Dghaim et al., 2015). The level of iron in this study may be below the quantity that could induce toxicity, especially as it is considered an essential nutritional requirement in human.

Cobalt is essential for methionine metabolism where it controls the transfer of enzymes such as homocysteine methyltransferase (Prashanth et al., 2015; Izah et al., 2016). High concentrations may lead to diarrhea (Izah et al., 2016). Also, the limit of cobalt in herbal medicines is yet to be established. 
Table2. Level of selected heavy metals in powdered herbal medicine sold in Nigeria

\begin{tabular}{|l|l|l|l|l|l|}
\hline Sample code & $\mathrm{Ni}(\mathrm{mg} / \mathrm{kg})$ & $\mathrm{Zn}(\mathrm{mg} / \mathrm{kg})$ & $\mathrm{Pb}(\mathrm{mg} / \mathrm{kg})$ & $\mathrm{Fe}(\mathrm{mg} / \mathrm{kg})$ & $\mathrm{Co}(\mathrm{mg} / \mathrm{kg})$ \\
\hline MHP & $<0.001 \pm 0.000$ & $<0.001 \pm 0.000 \mathrm{a}$ & $<0.001 \pm 0.000$ & $15.253 \pm 0.248 \mathrm{c}$ & $.014 \pm 0.0 .004 \mathrm{~b}$ \\
\hline GWM & $<0.001 \pm 0.000$ & $<0.001 \pm 0.000 \mathrm{a}$ & $<0.001 \pm 0.000$ & $6.817 \pm 0.086 \mathrm{a}$ & $<0.001 \pm 0.000 \mathrm{a}$ \\
\hline UNP & $<0.001 \pm 0.000$ & $0.241 \pm 0.21 \mathrm{~b}$ & $<0.001 \pm 0.000$ & $16.309 \pm 0.520 \mathrm{~d}$ & $<0.001 \pm 0.000 \mathrm{a}$ \\
\hline ORG & $<0.001 \pm 0.000$ & $0.231 \pm 0.31 \mathrm{~b}$ & $<0.001 \pm 0.000$ & $9.120 \pm 0.165 \mathrm{~b}$ & $<0.001 \pm 0.000 \mathrm{a}$ \\
\hline GSH & $<0.001 \pm 0.000$ & $<0.001 \pm 0.000 \mathrm{a}$ & $<0.001 \pm 0.000$ & $8.863 \pm 0.026 \mathrm{~b}$ & $<0.001 \pm 0.000 \mathrm{a}$ \\
\hline
\end{tabular}

Data is expressed as mean \pm standard deviation; Different letters along the column indicate significant variations $(P<0.05)$ according to Waller Duncan statistics

\section{CONCLUSION}

Macro nutrient (calcium, sodium, potassium and magnesium) and trace metals (zinc, iron, cobalt and nickel) play essential roles in growth and development in humans. Herbal medicine is used in several regions of the world especially in developing nations. This study evaluated the macro and selected trace elements in some powdered herbal medicines sold in Nigeria. The study reportedly revealed that nickel and lead were not trace metal components of powdered herbs. Cobalt and zinc were detected in $20 \%$ and $40 \%$ of herbal products studied. Iron was present in all test samples, and depicted the most abundant trace metal present. The levels of trace metals and macro nutrients obtained suggests that no major health challenge is been induced on consumers of such products. In addition, there is need for continuous monitoring of heavy metals in herbal products. This will help ensure that there are no potential health hazards associated with its regular consumption.

\section{ACKNOWLEDGEMENT}

The authors wish to thank Anal Concept Limited Port Harcourt, Nigeria for providing the laboratory facilities to carry out this research.

\section{REFERENCES}

[1] Abbaspour, N., Hurrel, R., and Kelishadi, R. (2014). Review on iron and its importance for human health. J. Res. Med. Sci., 19(2), 164-174.

[2] Aigberua, A. O., and Tarawou, T. (2017). Assessment of Heavy Metals in Muscle of Tilapia zilli from some Nun River Estuaries in the Niger Delta Region of Nigeria. Academic Journal of Chemistry, 2(9), 96101.

[3] Aigberua, A.O., Alagoa, K.J., and Izah, S.C. (2018). Macro Nutrient Composition in Selected Seasonings used in Nigeria. MOJ Food Processing and Technology, 6(4): 00155. DOI:10.15406/mojfpt.2018.06.00155.

[4] Aigberua, A.O., and Izah, S.C. (2019). pH Variation, Mineral Composition and Selected Trace Metal Concentration in Some Liquid Herbal Products Sold in Nigeria. International Journal of Research Studies in Biosciences, 7(1): 14- 21.

[5] Beard, J.L. (2001). Iron Biology in Immune Function, Muscle Metabolism and Neuronal Functioning. Journal of Nutrition, 131 (2), 568S-580S.

[6] Chasapis, C.T., Loutsidou, A.C., Spiliopoulou, C.A. and Stefanidou, M.E. (2012). Zinc and human health: an update. Archives of Toxicology, 86(4), 521-534.

[7] Das KK, Das SN, Dhundasi SA (2008). Nickel, its adverse health effects \& oxidative stress. Indian J. Med. Res., 128, 412-425

[8] Dghaim, R., Al Khatib, S., Rasool, H., and Khan, M.A. (2015). Determination of Heavy Metals Concentration in Traditional Herbs Commonly Consumed in the United Arab Emirates. Journal of Environmental and Public Health, 2015, http://dx.doi.org/10.1155/2015/973878.

[9] Epidi, J.O., Izah, S.C., and Ohimain, E.I. (2016a). Antibacterial and synergistic efficacy of extracts of Alstonia boonei tissues. British Journal of Applied Science, 1(1), 21 - 26.

[10] Epidi, J.O., Izah, S.C., Ohimain, E.I., and Epidi, T.T. (2016b). Antibacterial and synergistic potency of tissues of Vitex grandifolia. Biotechnological Research, 2(2), 69-76.

[11] Haas, E.M. (2011). Role of Potassium in Maintaining Health. http://hkpp.org/patients/potassium-health. Accessed September 26th, 2017 
[12] Idris, M.A., Kolo, B.G., Garba, S.T. and Waziri, I. (2013). Pharmaceutical industrial effluent: heavy metal contamination of surface water in Minna, Niger State, Nigeria. Bull. Environ. Pharm. Life Sci., 2(3), 4044.

[13] Izah, S.C. (2018). Some determinant factors of antimicrobial susceptibility pattern of plant extracts. Research and Review Insight, 2(3), 1-4

[14] Izah, S.C., and Aseibai, E.R. (2018). Antibacterial and Synergistic activities of methanolic leaf extract of Lemon grass (Cymbopogon citratus) and rhizome of Ginger (Zingiber officinale) against Escherichia coli, Staphylococcus aureus and Bacillus species. ACTA Microbiology, 1(6), 26-30.

[15] Izah, S.C., Uhunmwangho, E.J., and Eledo, B.O. (2018a). Medicinal potentials of Buchholzia coriacea (wonderful kola). Medicinal Plant Research, 8(5), 27-43.

[16] Izah, S.C., Zige, D.V., Alagoa, K.J., Uhunmwangho, E.J., and Iyamu, A.O. (2018b). Antibacterial Efficacy of Aqueous Extract of Myristica fragrans (Common Nutmeg). EC Pharmacology and Toxicology, 6(4), 291-295.

[17] Izah, S.C., Uhunmwangho, E.J., Dunga, K.E., and Kigigha, L.T. (2018c). Synergy of methanolic leave and stem-back extract of Anacardium occidentale 1. (cashew) against some enteric and superficial bacteria pathogens. MOJ Toxicology, 4(3), 209-211.

[18] Izah, S.C., Uhunmwangho, E.J., and Etim, N.G. (2018d). Antibacterial and synergistic potency of methanolic leaf extracts of Vernonia amygdalina L. and Ocimum gratissimum L. Journal of Basic Pharmacology and Toxicology, 2(1), 8-12

[19] Izah, S.C., Bassey, S.E., and Ohimain E.I. (2018e). Ecological risk assessment of heavy metals in cassava mill effluents contaminated soil in a rural community in the Niger Delta Region of Nigeria. Molecular Soil Biology, 9(1), 1-11.

[20] Izah, S.C., Inyang, I.R., Angaye, T.C.N., and Okowa, I.P. (2017a). A review of heavy metal concentration and potential health implications in beverages consumed in Nigeria. Toxics, 5 (1): 1-15.

[21] Izah, S.C., Bassey, S.E., and Ohimain E.I. (2017b). Geo-accumulation index, enrichment factor and quantification of contamination of heavy metals in soil receiving cassava mill effluents in a rural community in the Niger Delta region of Nigeria. Molecular Soil Biology, 8(2), 7-20.

[22] Izah, S.C., Bassey, S.E., and Ohimain E.I. (2017c). Assessment of heavy metal in cassava mill effluent contaminated soil in a rural community in the Niger Delta region of Nigeria. EC Pharmacology and Toxicology, 4(5), 186-201.

[23] Izah, S.C., Bassey, S.E., and Ohimain E.I. (2017d). Assessment of pollution load indices of heavy metals in cassava mill effluents contaminated soil: a case study of small-scale cassava processing mills in a rural community of the Niger Delta region of Nigeria. Bioscience Methods, 8(1), 1-17.

[24] Izah, S.C., Bassey, S.E., and Ohimain, E.I. (2017e). Cyanide and Macro-Nutrients Content of Saccharomyces cerevisiae Biomass Cultured in Cassava Mill Effluents. International Journal of Microbiology and Biotechnology, 2(4), 176-180.

[25] Izah, S.C., and Aigberua, A.O. (2017). Comparative Assessment of selected heavy metals in some common edible vegetables sold in Yenagoa metropolis, Nigeria. Journal of Biotechnology Research, 3(8), $66-71$.

[26] Izah, S.C., Chakrabarty, N., and Srivastav, A.L. (2016). A Review on Heavy Metal Concentration in Potable Water Sources in Nigeria: Human Health Effects and Mitigating Measures. Exposure and Health, 8, 285-304.

[27] Izah, S.C., and Angaye, T.C.N. (2016). Heavy metal concentration in fishes from surface water in Nigeria: Potential sources of pollutants and mitigation measures. Sky Journal of Biochemistry Research, 5(4): 3147

[28] Kigigha, L.T., Selekere, R.E., and Izah, S.C. (2018a). Antibacterial and synergistic efficacy of acetone extracts of Garcinia kola (Bitter kola) and Buchholzia coriacea (Wonderful kola). Journal of Basic Pharmacology and Toxicology, 2(1), 13-17.

[29] Kigigha, L.T., Izah, S.C., and Uhunmwangho, E.J. (2018b). Assessment of hot water and ethanolic leaf extracts of Cymbopogon citratus Stapf (Lemon grass) against selected bacteria pathogens. Annals of Microbiology and Infectious Diseases, 1(3), 1- 5. 
[30] Kigigha, L.T., Nyenke, P., and Izah, S.C. (2018c). Health risk assessment of selected heavy metals in gari (cassava flake) sold in some major markets in Yenagoa metropolis, Nigeria. MOJ Toxicol. 4(2), 47-52.

[31] Kigigha, L.T., Ebieto, L.O., and Izah, S.C. (2017). Health risk assessment of heavy metal in smoked Trachurus trachurus sold in Yenagoa, Bayelsa state, Nigeria. International Journal of Healthcare and Medical Sciences, 3(9), $62-69$.

[32] Kigigha, L.T., Biye, S.E. and Izah, S.C. (2016). Phytochemical and antibacterial activities of Musanga cecropioides tissues against Escherichia coli, Pseudomonas aeruginosa Staphylococcus aureus, Proteus and Bacillus species. International Journal of Applied Research and Technology, 5(1), 100 - 107.

[33] Kigigha, L.T., Izah, S.C., and Ehizibue, M. (2015). Activities of Aframomum melegueta Seed Against Escherichia coli, S. aureus and Bacillus species. Point Journal of Botany and Microbiology Research, $1(2), 23-29$.

[34] Lieu, P.T., Heiskala, M., Peterson, P.A., and Yang, Y. (2002). The roles of iron in health and disease. Mol. Aspects Med., 22(1-2), 1-87.

[35] Muhammad, I., Ashiru, S., Ibrahim, I.D., Salawu, K., Muhammad, D.T., and Muhammad, N.A. (2014). Determination of some heavy metals in wastewater and sediment of artisanal gold local mining site of Abare Area in Nigeria. Journal of Environmental Treatment Techniques, 1(3), 174-182.

[36] Onimisi, B.H., Kasim, L.S., Bamigboye, C.Y., and Adeoti, O.A. (2016). The Health Benefits of Heavy Metals in Herbal Drinks, Nigeria. Journal of Pharmaceutical Research, 1, 1-5.

[37] Opoku-Okrah, C., Acquah, B. K.S., and Dogbe, E.E. (2015). Changes in potassium and sodium concentrations in stored blood. The Pan African Medical Journal, 20:236. doi:10.11604/pamj. 2015.20.236.5851

[38] Palacios, C. (2006). The Role of Nutrients in Bone Health, from A to Z. Critical Reviews in Food Science and Nutrition, 46:621-628.

[39] Prashanth, L., Kattapagari, K.K., Chitturi, R.T., Baddam, V.R.R., and Prasad, L.K. (2015). A review on role of essential trace elements in health and disease. Journal of Dr. NTR University of Health Sciences, 4(2) 75-78.

[40] Umar, A., Mohammed, Y., Garba, S., and Faruruwa, M.D. (2016). Quantitative Determination of Heavy Metals in Some Commonly Consumed Herbal Medicines in Kano State, Nigeria. Journal of Scientific and Engineering Research, 3(2): 1-8.

[41] World Health Organization (2007). WHO guidelines for assessing quality of herbal medicines with reference to contaminants and residues. Geneva, Switzerland. ISSN ISBN 9789241594

Citation: Ayobami Omozemoje Aigberua \& Sylvester Chibueze Izah (2019). Macro Nutrient and Selected Heavy Metals in Powered Herbal Medicine Sold in Nigeria. International Journal of Medicinal Plants and Natural Products (IJMPNP), 5(1), pp.23-29. http://dx.doi.org/10.20431/2454-7999.0501004

Copyright: () 2019 Authors, This is an open-access article distributed under the terms of the Creative Commons Attribution License, which permits unrestricted use, distribution, and reproduction in any medium, provided the original author and source are credited. 